\title{
Free and attached cells of Bacillus subtilis as starters for production of a soup flavouring ("ogiri egusi”)
}

\author{
Chika C. Ogueke*, Clifford I. Owuamanam, Ann I. Peter-Ikechukwu and Ihuoma Ahaotu
}

\author{
Department of Food Science and Technology, Federal University of Technology, Owerri. P.M.B. 1526 Owerri, Nigeria.
} E.mail: chikaogueke@yahoo.com

Received 11 September 2012; Received in revised form 28 September 2012; Accepted 4 October 2012

\begin{abstract}
Aims: This Bacillus subtilis has been identified to be the main fermenting bacterium during indigenous production of "ogiri egusi"; a traditional soup flavouring rich in protein. Evaluation of the use of starter and broth cultures of this bacterium in the production of 'ogiri egusi' was therefore undertaken with the view to improve the fermentation process and quality of product.

Methodology and Results: Cowpea granules in association with Bacillus subtilis cells were developed as starter cultures for the fermentation. Results obtained showed that the starter cultures resulted in an increase in the aminonitrogen from $1.67 \pm 0.02$ to $19.96 \pm 0.05 \mathrm{mg} \mathrm{N} / 100 \mathrm{~g}$ dry matter in $48 \mathrm{~h}$ while the broth cultures increased the aminonitrogen from $1.63 \pm 0.03$ to $16.54 \pm 0.05 \mathrm{mg} \mathrm{N} / 100 \mathrm{~g}$ dry matter in $72 \mathrm{~h}$. There was also a corresponding increase in the protease activity of the fermentation conducted with the starter cultures from $2.69 \pm 0.03$ to $54.98 \pm 0.04 \mathrm{mg} \mathrm{N} / \mathrm{min}$ in $48 \mathrm{~h}$. The broth cultures produced an increase from $2.65 \pm 0.02$ to $47.61 \pm 0.06 \mathrm{mg} \mathrm{N} / \mathrm{min}$ in $72 \mathrm{~h}$. Changes in these parameters for the natural process were gradual and reached their peaks at $120 \mathrm{~h}$ with values of $9.89 \pm 0.13 \mathrm{mg} \mathrm{N} / 100 \mathrm{~g} \mathrm{dry} \mathrm{matter}$ and $31.92 \pm 0.03 \mathrm{mg} \mathrm{N} / \mathrm{min}$ respectively. Peroxide values for the fermentation processes increased throughout the period; however the starter cultures produced the lowest value $(10.20 \pm 0.10 \mathrm{meq} / \mathrm{kg})$ showing that rancidity may not occur in the product fermented by the starter culture.

Conclusion, significance and impact of study: The starter cultures significantly reduced fermentation time from $96-$ $120 \mathrm{~h}$ in the natural process to $48 \mathrm{~h}$. Thus use of starter cultures optimized the process of fermentation and will eliminate chances of contamination of product with pathogens and spoilage organisms. This ultimately will improve product quality.
\end{abstract}

Keywords: Amino-nitrogen; Bacillus subtilis; ogiri egusi; protease activity; starter cultures

\section{INTRODUCTION}

'Ogiri egusi' is an indigenous fermented soup condiment which is used as flavoring agent whose character and organoleptic properties depend on microbial activities (Nwosu and Ojimelukwe, 2000). It has an oily gray pasty consistency with a very strong pungent smell when it is in its raw state. Consumed mainly in southern Nigeria especially by the igbos (Enwere, 1998), it is produced by traditional methods of uncontrolled solid substrate fermentation of melon seeds (Citrullus vulgaris shrads) (Achi, 2005). The raw seeds are boiled, the water drained and allowed to ferment naturally for four days in clay pots. The fermented seeds are then mashed into pastes, wrapped in leaves and kept over a fire place to dry. In Nigeria, melon is mostly cultivated in the south-eastern part and is usually inter-planted with yam and cassava where it serves as a cover crop (Ogueke and Nwagwu,
2007). Ogiri egusi is known to contribute to the caloric and protein intake and are generally added to soups as low-cost meat substitute by low income families in parts of Nigeria (Adewusi et al., 2004).

Melon seeds contain good levels of crude protein which are similar to soybean and fluted pumpkin. Crude protein content of melon seeds range from 24.3 to $41.6 \%$ dw (Fokou et al., 2004) while fat content range from 42.957.3\% (David and Aderibigbe, 2010; Fokou et al., 2004). Oils from melon seeds contain over $60 \%$ linoleic acid which is an essential fatty acid, $22 \%$ saturated acids (including myristic, palmitic, stearic acids) and $78 \%$ unsaturated fatty acids (including oleic, linoleic and linolenic acids) (Ogunsua, 2000). Egusi is a good source of essential amino acids especially tryptophan and methionine. Carbohydrate content of melon seeds range from 4.56-13.3\% dw (David and Aderibigbe, 2010; Fokou et al., 2004). 
Various workers have identified different microorganisms in fermented melon seeds. These include Bacillus sp., E.coli, Proteus sp., Pediococcus sp. and Alcaligenes sp. (Barber and Achinewhu, 1992; Barimalaa et al., 1989; Ofuya and Nnajiofor, 1989; Sanni et al., 2000). However, Bacillus subtilis and B. licheniformis have been identified as the main bacteria involved in the fermentation because of their ability to produce the requisite enzymes for the breakdown of proteins and production of the various flavor compounds associated with ogiri egusi (Barimalaa et al., 1989). Bacillus and Acinetobacter $\mathrm{sp}$, together with some yeast and fungi (Rhizopus) were identified in the fermented product developed from portions of melon (Citrullus vulgaris) and groundnut (Arachis hypogea) (Nwosu and Ojimelukwe, 2000).

Ogiri egusi fermentation is still carried out using the traditional method. This usually results in variation of quality of products (Ogueke and Nwagwu, 2007). There is also need to optimize the fermentation process with the view to industrialize the production. The use of chance fermentation as practiced traditionally makes the fermentation difficult to control and results in the contamination of products with pathogens or other microorganisms capable of producing toxins and those that cause off flavors (Ogueke and Nwagwu, 2007). These can also introduce undesirable and spoilage organisms which can cause a reduction in the product's shelf-life and increase susceptibility to spoilage. Due to these setbacks, variation in the quality and stability of the products are often observed.

Attempts have been made by a group of workers (Ogueke and Nwagwu, 2007) to produce ogiri egusi using pure cultures of the bacteria isolated from previous ogiri egusi, thus trying to introduce the use of starter cultures. The development of starter cultures for the production will enhance standardization of the product. The work therefore aims at evaluating the effect of Bacillus subtilis cells in association with cowpea granules, as starter cultures in 'ogiri egusi' fermentation when compared to the traditional indigenous method.

\section{MATERIALS AND METHODS}

\section{Material collection and preparation}

Approximately $15 \mathrm{~kg}$ of melon seeds (Citrullus vulgaris) were purchased from Ihiagwa market in Owerri, Imo State, Nigeria in November, 2011. Seeds obtained were dehulled and sorted to remove bad seeds, hulls and extraneous materials. The seeds were stored at $4{ }^{\circ} \mathrm{C}$ until used for the study. Approximately $5.0 \mathrm{~kg}$ of cowpea (Vigna unguiculata) was purchased from Owerri main market, Imo State, Nigeria and the seeds were properly sorted before use.

\section{Bacillus subtilis used for the study}

Bacteria were isolated from various ogiri egusi samples from three states of the consuming region of South
Eastern Nigeria. Microbiological analyses were conducted immediately by suspending $10 \mathrm{~g}$ of sample in $90 \mathrm{~mL}$ sterile maximum recovery diluent(MRD Oxoid CM0733 ) and homogenized using a Stomacher (A.J.Seward, BA6021) for 1 to $2 \mathrm{~min}$ at normal speed. Ten-fold dilutions were then prepared and $0.1 \mathrm{ml}$ of suitable dilution was spread onto Nutrient agar (NA, Oxoid CM0003). Plates were incubated aerobically at $37{ }^{\circ} \mathrm{C}$ for $24-48$ hours. Representative dominant colonies were picked and purified by streaking on same Nutrient agar. Stock cultures were kept in Nutrient broth containing $20 \%$ glycerol and stored at $-20^{\circ} \mathrm{C}$.

Prior to the genotyping, the Bacillus isolates were phenotyped according to Ouoba et al.(2008). Forty bacteria were chosen based on their phenotypic characteristics including colony and cell morphology, cell motility, presence of endospore, Gram and catalase reaction after growth on Nutrient agar (NA; Oxoid CM0003) for $24 \mathrm{~h}$. Fermentation profiles of carbohydrates (API 50CHB galleries; BioMerieux, Basingstoke, UK) were also determined to assist typing. This was done according to the manufacturer's instruction and results were analyzed using the apiweb software.

The identification of the isolates was done using the methods described by Ouoba et al. (2008). Thirty three out of the forty isolates were identified to be Bacillus subtilis. Thus $B$. subtilis was taken to be the main fermenting bacterium and then used for the fermentation. Before use the identified Bacillus subtilis were streaked on Tryptone Soy agar (BIOTEC) and incubated at $35{ }^{\circ} \mathrm{C}$ for $18 \mathrm{~h}$. The cultures were then washed by suspending the cells in $10 \mathrm{~mL}$ of $0.1 \mathrm{M}$ potassium phosphate buffer $(\mathrm{pH}$ 7.0). This was followed by centrifugation at $14000 \times \mathrm{xg}$ for 5 min using an MSE centrifuge (Minor, UK) (Njoku et al., 1990)

\section{Preparation of carrier granules}

The method of and Abu (2000) was used with minor modification as shown below. Cowpea (Vigna unguiculata) granules were prepared by immersing $500 \mathrm{~g}$ of well sorted raw seeds of black-eyed cowpea in $5 \mathrm{~L}$ of portable water, autoclaved at $121^{\circ} \mathrm{C}$ for $15 \mathrm{~min}$, cooled, drained and airdried. The boiled seeds were spread evenly on an aluminium foil and placed in a hot-air oven (WeissGallenkamp, UK) at $80{ }^{\circ} \mathrm{C}$ for $24-48 \mathrm{~h}$, then cooled. The cooled seeds were dry-milled using a warring blender, sieved into different particle sizes using a laboratory sieve (Endocotts Ltd, UK) and particles sizes of $700 \mu \mathrm{m}$ was collected. One gram (1 g) each was dispensed into MacCartney bottles and sterilized in a hot-air oven (Weiss-Gallenkamp, UK) at $100{ }^{\circ} \mathrm{C}$ for $18-24 \mathrm{~h}$ (with the lid loosely closed)

\section{Inoculum preparation and standardization of cultures}

Cultures from $18 \mathrm{~h}$ Tryptone Soy agar plates (BIOTECH) were examined for purity by microscopic examination of slides prepared from randomly selected colonies. A loopful of the $18 \mathrm{~h}$ old culture was inoculated in a flask 
containing $50 \mathrm{~mL}$ of Tryptone Soy broth (Oxoid) and was incubated aerobically for $48 \mathrm{~h}$ at $35^{\circ} \mathrm{C}$. Cells from the broth culture were harvested and washed three times with $0.1 \mathrm{M}$ potassium phosphate buffer by centrifugation at $14000 x g$ for $5 \mathrm{~min}$. The cells were then aseptically resuspended in $20 \mathrm{~mL}$ sterile $0.1 \mathrm{M}$ potassium phosphate buffer ( $\mathrm{pH}$ 7.0). The cell suspension was then standardized using a spectrophometer (Model S2100UV, UNICO, New Jersey, USA) at $550 \mathrm{~nm}$ wavelength such that $1.0 \mathrm{~mL}$ of the suspension contained about $3.0 \times 10^{8}$ cells.

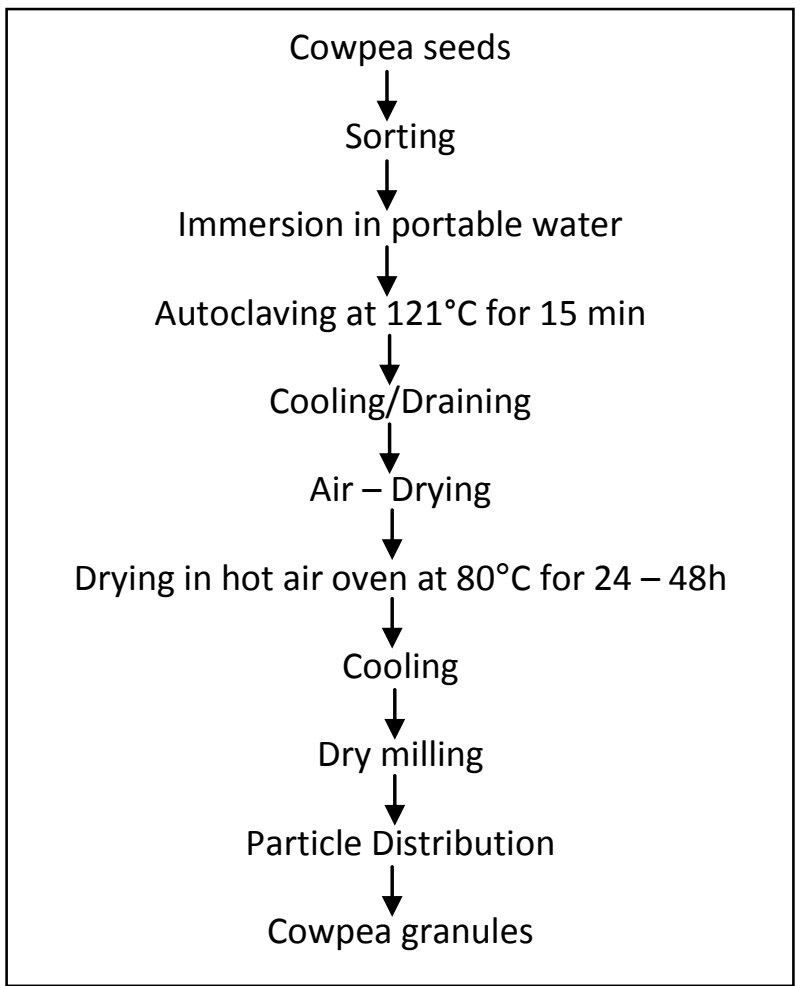

Figure 1: Flow diagram for production of Cowpea granules (carrier).

\section{Transfer of standardized cultures to cowpea granules (carrier)}

With a sterile pipette $0.2 \mathrm{~mL}$ of the standardized suspension of $B$. subtilis was aseptically transferred into different parts of $1.0 \mathrm{~g}$ of the sterile cowpea granules in the Mac Carthney bottles in an inoculation chamber. The contents of the bottles were thoroughly mixed by inversion of the bottles at the rate of 20 times per min for 5 min (Monela et al., 1985). They were then transferred to a rotary shaker to shake them for 5 min (Husmark and Ronner, 1990). The granules with attached Bacillus cells were dried using sterile air from a monopoint dryer (Type 4547, Braun Ag, UK) until a final moisture level of $10 \%$ was attained. The attached cells were stored at $4{ }^{\circ} \mathrm{C}$ until used for the study. These served as starter cultures.
Standardized broth cultures of $B$. subtilis were also prepared $(1.0 \mathrm{~mL}$ of broth culture contained about $3.0 \mathrm{x}$ $10^{8}$ cells) and used to ferment melon seeds for 'ogiri egusi' production.

\section{Fermentation of melon seeds using starter cultures and standardized broth cultures of $B$. subtilis}

Two kilograms of dehulled melon seeds were properly sorted and cleaned, and extraneous materials removed. The seeds were boiled for 2-3 $\mathrm{h}$ until the endosperm softened, then drained and cooled to about $30^{\circ} \mathrm{C}$, placed into a sterilized container and inoculated with $10 \mathrm{~g}$ of the starter cultures of $B$. subtilis. This was aseptically mixed and allowed to ferment for four days at ambient temperature $\left(30-32^{\circ} \mathrm{C}\right)$.

For the fermentation using standardized broth cultures, $2.0 \mathrm{~kg}$ of the melon seeds were treated as above except that the boiled and cooled seeds were inoculated with $2.0 \mathrm{~mL}$ of the standardized broth cultures.

\section{Natural fermentation of melon seeds for ogiri egusi}

This was also prepared as above. However, after boiling and cooling the seeds were allowed to ferment naturally without the addition of the starter cultures or the standardized broth cultures.

The fermentations were monitored for the protease activities, amino nitrogen content, $\mathrm{pH}$, titratable acidity, and peroxide value. All analyses were carried out in triplicate.

\section{Determination of $\mathrm{pH}$}

The $\mathrm{pH}$ of each fermentation process was measured as follows. Five grams of fermenting seeds was taken from the bulk and mashed in $45 \mathrm{~mL}$ of sterile deionized water (Njoku et al., 1990). The $\mathrm{pH}$ was measured using a digital $\mathrm{pH}$ meter (Jenway $\mathrm{pH} / \mathrm{MV} / \mathrm{TEMPERATURE}$ METER, Model 3510, Essex, UK) at ambient temperature (30-32 $\left.{ }^{\circ} \mathrm{C}\right)$. Before use the $\mathrm{pH}$ meter was standardized using buffers $(4.0-9.0)$.

\section{Determination of titratable acidity of fermenting seeds}

Chilled distilled water $(2 \mathrm{~mL})$ was added to $5 \mathrm{~g}$ of fermenting mash in a chilled mortar. The sample was crushed with a pestle and then transferred to $100 \mathrm{~mL}$ flask. An additional $10 \mathrm{~mL}$ of chilled extractant was added and thereafter the flask was stoppered and shaken on a Staurt flask shaker at medium speed for $15 \mathrm{~min}$. The extracts were then centrifuged at $2300 \mathrm{xg}$ in a bench-top MSE centrifuge at $5{ }^{\circ} \mathrm{C}$. The residue was re-suspended in $8 \mathrm{~mL}$ of chilled extractant and subjected to the same procedure. The supernatants were combined and made up to $20 \mathrm{~mL}$ with chilled extractant (Njoku and Okemadu, 1989). Ten milliliters of the extract was then titrated with $0.1 \mathrm{M} \mathrm{NaOH}$ using phenolphthalein as indicator. A blank was prepared using $10 \mathrm{~mL}$ distilled water. The titrable acidity was calculated as $\mathrm{mg}$ lactic $\mathrm{acid} / \mathrm{g}$ of sample. 


\section{Determination of peroxide value}

Fifteen grams of fermenting seeds was mashed and $5 \mathrm{~g}$ each of the mashed seeds was placed into a $250 \mathrm{~mL}$ glass - stoppered Erlenmeyer flask, and $30 \mathrm{~mL}$ of solvent mixture ( 3 parts by volume of Glacial acetic acid +2 parts by volume of Chloroform) was added. The flask was swirled to dissolve the mashed seeds in the solution. Five hundred microliters of saturated potassium iodide solution was added and the solution was allowed to stand (with occasional shaking) for $1 \mathrm{~min}$, then $30 \mathrm{~mL}$ of distilled water was added. The mixture was titrated by gradually adding $0.1 \mathrm{~N}$ sodium thiosulphate and constantly shaking vigorously. The titration continued until the yellow color had almost disappeared. Five hundred microliters of starch indicator solution was added. The titration was continued, shaking the flask vigorously at near end point until the iodine from the chloroform layer was liberated. The sodium thiosulphate was then added until the blue color had just disappeared. The tubes were placed in boiling water to boil for about $30 \mathrm{sec}$. A blank was also prepared at the same time. The peroxide value as milliequivalent of perioxides per $1000 \mathrm{~g}$ of sample was calculated using the equation described below:

$$
\begin{aligned}
& \text { Peroxide value }=\frac{(\mathrm{S}-\mathrm{B}) \times(\mathrm{N}) \times(1000)}{\mathrm{W}} \\
& \mathrm{B}=\text { Titration of blank } \\
& \mathrm{S}=\text { Titration of sample } \\
& \mathrm{W}=\text { Weight of sample } \\
& \mathrm{N}=\text { Normality of sodium thiosulfate solution }
\end{aligned}
$$

\section{Amino nitrogen determination}

The formol titration method (Pham and Del-Rosario, 1983) was used. Three grams of fermenting seeds was taken and mashed. Two grams of the mashed seeds was placed in a conical flask, and then $0.5 \mathrm{~mL}$ of phenolphthalein $(0.5 \%)$ and $0.4 \mathrm{~mL}$ of neutral saturated potassium oxalate were added. The mixture was kept to stand for few minutes and this was neutralized with $0.1 \mathrm{M} \mathrm{NaOH}$ to a standard pink color. Two milliliters of $40 \%$ formaldehyde solution was added and allowed to stand for few minutes (until mixture was colorless). This was then titrated with
$0.1 \mathrm{M} \mathrm{NaOH}$ to pink color. The titer value obtained was designated ' $V_{1}$ '. A blank was run by titrating a mixture of 2 $\mathrm{mL}$ of formaldehyde solution and $10 \mathrm{~mL}$ distilled water with $0.1 \mathrm{M} \mathrm{NaOH}$ to obtain ' $\mathrm{V} 2$ '. The amino nitrogen was calculated using the equation: \% Amino Nitrogen $=1.7\left(\mathrm{~V}_{1}\right.$ $\left.-\mathrm{V}_{2}\right)$.

\section{Determination of protease activity}

The protease activity of the fermenting materials was determined using the modified casein digestion method as described by Isu and Njoku (1997). Five milliliters of a $10 \%(w / v)$ homogenate of the fermenting material was used. Enzyme activity was expressed as amino nitrogen production. One unit of enzyme activity was equivalent to the amount of enzyme required to release $1 \mu \mathrm{g}$ amino nitrogen under the assay conditions.

\section{Analysis of data}

The data obtained from this study were statistically analyzed using Analysis of Variance (ANOVA). The means were separated using Fischer's least significant difference (LSD) at $p \leq 0.05$ confidence level. Microsoft Excel 2007 was used for the analysis.

\section{RESULTS AND DISCUSSION}

\section{Evaluation of $\mathrm{pH}$ during fermentation}

For all treatments, there was a drop in the $\mathrm{pH}$ value within the first $24 \mathrm{~h}$ of fermentation (Table 1), but an increase was observed afterwards. The drop in $\mathrm{pH}$ could be attributed to the production of organic acids from the utilization of the little amount of carbohydrate present (19). Melon seeds contain 4.56-13.3\% dw carbohydrate (David and Aderibigbe, 2010; Fokou et al., 2004). The rise in $\mathrm{pH}$ after $24 \mathrm{~h}$ could be due to the abundant production of ammonia during fermentation from protein hydrolysis, and deaminase activity following utilization of amino acids as carbon and energy sources by the fermenting bacteria (Njoku and Okemadu, 1989; Ogueke and Nwagwu, 2007). The increase in $\mathrm{pH}$ may have encouraged the growth of Bacillus subtilis, hence increasing fermentation rate.

Table 1: Mean values of $\mathrm{pH}$ change during fermentation of melon seeds

\begin{tabular}{|l|c|c|c|c|c|}
\hline \multirow{2}{*}{$\begin{array}{l}\text { Fermentation } \\
\text { Treatment }\end{array}$} & \multicolumn{5}{|c|}{ Fermentation Period (Hour) } \\
\cline { 2 - 6 } & 0 & 24 & 48 & 72 & 96 \\
\hline Starter cultures & $6.46 \pm 0.02^{\mathrm{a}}$ & $5.9 \pm 0.10^{\mathrm{a}}$ & $7.9 \pm 0.35^{\mathrm{a}}$ & $8.0 \pm 0.02^{\mathrm{a}}$ & $8.1 \pm 0.40^{\mathrm{a}}$ \\
\hline Broth cultures & $6.49 \pm 0.03^{\mathrm{a}}$ & $6.1 \pm 0.11^{\mathrm{a}, \mathrm{b}}$ & $7.7 \pm 0.41^{\mathrm{a}}$ & $7.8 \pm 0.30^{\mathrm{a}, \mathrm{b}}$ & $8.0 \pm 0.29^{\mathrm{a}}$ \\
\hline Natural & $6.48 \pm 0.04^{\mathrm{a}}$ & $6.3 \pm 0.14^{\mathrm{b}}$ & $7.4 \pm 0.15^{\mathrm{b}}$ & $7.6 \pm 0.28^{\mathrm{b}}$ & $7.7 \pm 0.18^{\mathrm{b}}$ \\
\hline
\end{tabular}

${ }^{\mathrm{ab}}$ Mean with different superscripts within each column are significantly different $(p \leq 0.05)$ 
Bacillus sp have been found to give better fermentation of African Oilbean seeds for ugba at higher $\mathrm{pH}$ values (Odunfa and Oyeyiola, 1985). Other workers have also observed an increase in $\mathrm{pH}$ during ogiri egusi production (Adewusi et al., 2004; Barber and Achinewhu, 1992; David and Aderibigbe, 2010; Ogunsanwo et al., 1989; Steinkraus, 1995).

However, in this study the $\mathrm{pH}$ of the broth cultures and starter cultures were above 7.0 at $48 \mathrm{~h}$ fermentation, an indication of period of intense microbial activity, especially the fermentation with the starter cultures. The values obtained for the starter and broth culture fermented mashes were significantly different $(p \leq 0.05)$ from that produced by the natural fermentation at $48 \mathrm{~h}$. This has not been observed by other workers whose $\mathrm{pH}$ were about 7.0 or less at $48 \mathrm{~h}$ fermentation. Thus the use of starter cultures and broth cultures of $B$. subtilis reduced fermentation time. This agrees with the statement of Achi (2005) and observations of Ofuya and Nnajiofor (1989) that the use of starter cultures reduces fermentation time as well as guarantee product quality.

\section{Evaluation of titratable acidity during fermentation}

There was an initial increase in the total titratable acidity within $24 \mathrm{~h}$ (Table 2) due to production of organic acids
(Ogueke and Nwagwu, 2007). These were in agreement with earlier works by David and Aderibigbe (2010). However, after $24 \mathrm{~h}$ the titratable acidity decreased. The reduction in titratable acidity afterwards could be attributed to 'alkaline fermentation' (Steinkraus, 1995) and increased protease and deaminase activities (Njoku and Okemadu, 1989).

\section{Evaluation of peroxide value during fermentation}

Peroxide value for all treatments showed a remarkable increase as fermentation period increased (Table 3). However, the values did not exceed the threshold value of 30 milliequivalent of active oxygen per $\mathrm{kg}$ of oil in oil rich foods (like melon seeds) (Gotoh and Wada, 2006). The fermentation carried out by starter cultures of Bacillus cells had the least peroxide value $(10.20 \mathrm{Meq} / \mathrm{kg})$ within $96 \mathrm{~h}$ while the natural fermentation had the highest value $(14.00 \mathrm{Meq} / \mathrm{kg})$. A value of $30 \mathrm{Meq} / \mathrm{kg}$ indicate the initial stage of fat and oil deterioration (Gotoh and Wada, 2006). Since the peroxide value is used as a measurement of the extent to which rancidity can occur (Ihekoronye and Ngoddy, 1985) the lower values obtained with the starter cultures showed that the chances of the product going rancid is very low.

Table 2: Mean values of Total Titratable Acidity (\% Lactic acid) of fermenting melon seeds

\begin{tabular}{|l|c|c|c|c|c|}
\hline \multirow{2}{*}{$\begin{array}{l}\text { Fermentation } \\
\text { Treatment }\end{array}$} & \multicolumn{5}{|c|}{ Fermentation Period (Hour) } \\
\cline { 2 - 6 } & 0 & 24 & 48 & 72 & 96 \\
\hline Starter cultures & $0.28 \pm 0.04^{\mathrm{b}}$ & $0.79 \pm 0.06^{\mathrm{a}}$ & $0.21 \pm 0.05^{\mathrm{b}}$ & $0.19 \pm 0.04^{\mathrm{b}}$ & $0.18 \pm 0.06^{\mathrm{b}}$ \\
\hline Broth cultures & $0.24 \pm 0.04^{\mathrm{b}}$ & $0.74 \pm 0.05^{\mathrm{a}, \mathrm{b}}$ & $0.24 \pm 0.03^{\mathrm{a}, \mathrm{b}}$ & $0.23 \pm 0.05^{\mathrm{a}, \mathrm{b}}$ & $0.22 \pm 0.05^{\mathrm{a}, \mathrm{b}}$ \\
\hline Natural & $0.38 \pm 0.04^{\mathrm{a}}$ & $0.69 \pm 0.05^{\mathrm{b}}$ & $0.28 \pm 0.04^{\mathrm{a}}$ & $0.26 \pm 0.04^{\mathrm{a}}$ & $0.25 \pm 0.05^{\mathrm{a}}$ \\
\hline
\end{tabular}

${ }^{a b}$ Mean with different superscripts within each column are significantly different $(p \leq 0.05)$

Table 3: Mean values of Peroxide value of fermenting melon seeds (Meq/kg)

\begin{tabular}{|l|c|c|c|c|c|}
\hline \multirow{2}{*}{$\begin{array}{l}\text { Fermentation } \\
\text { Treatment }\end{array}$} & \multicolumn{5}{|c|}{ Fermentation Period (Hour) } \\
\cline { 2 - 6 } & 0 & 24 & 48 & 72 & 96 \\
\hline Starter cultures & $7.60 \pm 0.17^{\mathrm{a}}$ & $7.80 \pm 0.03^{\mathrm{c}}$ & $8.60 \pm 0.03^{\mathrm{c}}$ & $9.20 \pm 0.07^{\mathrm{c}}$ & $10.20 \pm 0.10^{\mathrm{c}}$ \\
\hline Broth cultures & $7.60 \pm 0.20^{\mathrm{a}}$ & $9.00 \pm 0.27^{\mathrm{b}}$ & $9.80 \pm 0.05^{\mathrm{b}}$ & $11.00 \pm 0.27^{\mathrm{b}}$ & $12.80 \pm 0.07^{\mathrm{b}}$ \\
\hline Natural & $7.80 \pm 0.20^{\mathrm{a}}$ & $10.80 \pm 0.91^{\mathrm{a}}$ & $11.40 \pm 0.03^{\mathrm{a}}$ & $12.00 \pm 0.24^{\mathrm{a}}$ & $14.00 \pm 0.23^{\mathrm{a}}$ \\
\hline
\end{tabular}

${ }^{a b c}$ Mean with different superscripts within each column are significantly different $(p \leq 0.05)$ 


\section{Evaluation of amino-nitrogen during fermentation}

Table 4 showed that there was an increase in the amino nitrogen for all the fermentation processes. This implied an increase in the rate of hydrolysis of the protein content by the proteinase enzyme, thus an indication of an increase in fermentation rate. The results also showed that the amino-nitrogen production was highest for the fermentation that employed starter cultures of Bacillus. Statistical analysis showed that values obtained with starter cultures were significantly different $(p \leq 0.05)$ from the pure culture and naturally fermented mashes from 24 $h$ to the end of fermentation. This also showed that association of the cells with cowpea granules will help increase the activity of the micro-organisms and release of enzymes for optimum fermentation activity. The aminonitrogen for the fermentation conducted with the starter cultures attained its peak at $48 \mathrm{~h}$, still indicating that the period is the peak of microbial activity and a reduction in fermentation time from $96-120 \mathrm{~h}$ with the traditional method to $48 \mathrm{~h}$ with the starter cultures.

\section{Evaluation of protease activity during fermentation}

Table 5 shows the protease activities of the cultures during the fermentations. From the results it could be observed that the protease activity of the fermentation conducted with the starter cultures increased rapidly and reached its peak at $48 \mathrm{~h}(54.96 \mathrm{mg} \mathrm{N} / \mathrm{min})$. This was followed by the fermentation carried out by the broth cultures of the bacterium which attained its highest value at $72 \mathrm{~h}$ (47.54 $\mathrm{mg} \mathrm{N} / \mathrm{min})$. These periods for the starter cultures corresponded with periods when the aminonitrogen and $\mathrm{pH}$ values attained their peaks, especially the $\mathrm{pH}$ which is the value obtained in a well fermented ogiri egusi after $120 \mathrm{~h}$ fermentation through the natural, traditional method (Adewusi et al., 2004; Barber and Achinewhu, 1992; Steinkraus, 1995). Statistical analysis showed that the natural fermentation did not produce significant $(p>0.05)$ changes in the protease activity and amino-nitrogen within the period. There was also a significant difference $(p<0.05)$ in these parameters between the starter cultures and broth cultures indicating that the starter cultures have better prospects for use in the production of ogiri egusi, which will also reduce fermentation time to $48 \mathrm{~h}$. Therefore use of starter cultures should be encouraged to guarantee product quality. This will also enhance optimization of the production process. Further studies need to be conducted to determine the effect of fermentation variables (relative humidity, temperature and oxygen transfer) on the overall fermentation process.

Table 4: Mean values of Amino nitrogen of fermenting melon seeds (mg N/100g)

\begin{tabular}{|l|c|c|c|c|c|}
\hline \multirow{2}{*}{$\begin{array}{l}\text { Fermentation } \\
\text { Treatment }\end{array}$} & \multicolumn{5}{|c|}{ Fermentation Period (Hour) } \\
\cline { 2 - 6 } & 0 & 24 & 48 & 72 & 96 \\
\hline Starter cultures & $1.67 \pm 0.02^{\mathrm{a}}$ & $10.8 \pm 0.03^{\mathrm{a}}$ & $19.96 \pm 0.05^{\mathrm{a}}$ & $17.81 \pm 0.04^{\mathrm{a}}$ & $16.93 \pm 0.06^{\mathrm{a}}$ \\
\hline Broth cultures & $1.63 \pm 0.03^{\mathrm{a}}$ & $5.79 \pm 0.06^{\mathrm{b}}$ & $11.35 \pm 0.03^{\mathrm{b}}$ & $16.54 \pm 0.05^{\mathrm{a}}$ & $13.70 \pm 0.04^{\mathrm{b}}$ \\
\hline Natural & $1.66 \pm 0.04^{\mathrm{a}}$ & $3.71 \pm 0.04^{\mathrm{c}}$ & $5.26 \pm 0.04^{\mathrm{c}}$ & $7.47 \pm 0.05^{\mathrm{b}}$ & $9.89 \pm 0.13^{\mathrm{c}}$ \\
\hline
\end{tabular}

${ }^{a b c}$ Mean with different superscripts within each column are significantly different $(p \leq 0.05)$

Table 5: Mean values of protease activity during fermentation of melon seeds ( $\mathrm{mg} \mathrm{N} / \mathrm{min}$ )

\begin{tabular}{|l|c|c|c|c|c|}
\hline \multirow{2}{*}{$\begin{array}{l}\text { Fermentation } \\
\text { Treatment }\end{array}$} & \multicolumn{5}{|c|}{ Fermentation Period (Hour) } \\
\cline { 2 - 6 } & 0 & 24 & 48 & 72 & 96 \\
\hline Starter cultures & $2.69 \pm 0.03^{\mathrm{a}}$ & $29.84 \pm 0.02^{\mathrm{a}}$ & $54.98 \pm 0.04^{\mathrm{a}}$ & $50.63 \pm 0.02^{\mathrm{a}}$ & $41.87 \pm 0.04^{\mathrm{a}}$ \\
\hline Broth cultures & $2.65 \pm 0.02^{\mathrm{a}}$ & $13.99 \pm 0.05^{\mathrm{b}}$ & $37.38 \pm 0.02^{\mathrm{b}}$ & $47.61 \pm 0.06^{\mathrm{b}}$ & $37.68 \pm 0.03^{\mathrm{b}}$ \\
\hline Natural & $2.68 \pm 0.02^{\mathrm{a}}$ & $3.73 \pm 0.02^{\mathrm{c}}$ & $14.36 \pm 0.03^{\mathrm{c}}$ & $27.53 \pm 0.04^{\mathrm{c}}$ & $31.92 \pm 0.03^{\mathrm{c}}$ \\
\hline
\end{tabular}

${ }^{a b c}$ Mean with different superscripts within each column are significantly different $(p \leq 0.05)$ 


\section{CONCLUSION}

Fermented melon seeds "ogiri egusi" is an indigenous fermented soup condiment that constitutes an important social agro-sustainable business that guarantees an additional income to families. Cowpea granules in association with $B$. subtilis cells were developed as starter cultures for the fermentation. During fermentation higher levels of protease activity and amino nitrogen were observed with the starter culture fermented samples, thus resulting in a significant reduction in fermentation time from $96-120 \mathrm{~h}$ in natural fermentation to $48 \mathrm{~h}$. Such starters could be explored to improve production and guarantee product quality. This will also create wealth and financial benefits. Further studies need to be conducted to determine the effect of fermentation variables (relative humidity, temperature and oxygen transfer) on the overall fermentation process.

\section{REFERENCES}

Achi, O. K. (2005). Traditional fermented condiments in Nigeria. African Journal of Biotechnology. 4 (13): 1612 - 1621.

Adewusi, S. R. A., Omafuvbe, B. O., Falade, O. S. and Osuntogun, B. A. (2004). Chemical and biochemical changes in African locust bean (Parkia biglobosa) and melon seeds (Citrullus vulgaris) during fermentation to condiments. Pakistan Journal of Nutrition. 3 (3): 140 - 145.

Barber, L. I. and Achinewhu, S. C. (1992). Microbiology of ogiri production from melon Seeds (Citrullus vulgaris). Nigerian Food Journal. 10: 129 - 135.

Barimalaa, I. S., Achinewhu, S. C., Yibatima, I. and Amadi, E. N. (1989). Studies on the solid state fermentation of bambara groundnut (Vigna subterranean L.). Journal of Science of Food and Agriculture. 66: 443 - 451.

David, O. M. and Aderibigbe, E. Y. (2010). Microbiology and proximate composition of 'ogiri', a pastry produced from different melon seeds. New York Science Journal. 3 (4): 18 - 27.

Enwere, N. J. (1998). Food of plant origin. Afro-orbis Publishers, Nigeria. pp. 24 - 71

Fokou, E., Achu, M. B. and Tchounguep, F. M. (2004). Preliminary nutritional evaluation of five species of egusi seeds in Cameroon. African Journal of Food, Agriculture, Nutrition and Development. 4 (1): 8.

Gotoh, N. and Wada, S. (2006). Importance of peroxide value in assessing food quality and food safety. Journal of the American Oil Chemists' Society. 83(5): 473 - 474.

Husmark, U. and Ronner, U. (1990). Forces involved in adhesion of Bacillus cereus spores to solid surfaces under different environmental conditions. Journal of Applied Bacteriology. 69: 557 - 562.

Ihekoronye, A.I. and Ngoddy, P.O (1985). Integrated food science and technology for the tropics. Macmillian Publishers, London. pp.123 - 127.
Isu, N. R. and Abu, G. O. (2000). An evaluation of the effect of Bacillus cells and Bacillus spores in association with cowpea granules as starter cultures for the fermentation of African oil bean (Pentaclethra macrophylla Bentham) to 'ugba'. Plant Foods for Human Nutrition. 55: 127 - 138.

Isu, N. R. and Njoku, H. O. (1997). An evaluation of the microflora associated with fermented African oil bean (Pentaclethra macrophylla) seeds during ugba production. Plant Foods for Human Nutrition. 51: 145 - 157.

Monela,B., Halfpap, L. and Birdsell, D. (1985). Langmuir and scatchard parameters do not describe the binding of Actinomyces viscosus treated hydroxyapatite. Journal of General Microbiology. 131: $2619-2626$.

Njoku, H. O., Ogbulie, J. N. and Nnubia, C. (1990). African oil bean (Pentaclethra macorphylla Bentham) for ugba production. Journal of Food Science. 49: 13-26.

Njoku, H. O. and Okemadu, C. P. (1989). Biochemical changes during the natural fermentation of the African oilbean (Pentaclethra macrophylla) for the production of ugba. Journal of Science of Food and Agriculture. 49: 457 - 465.

Nwosu, C. D. and Ojimelukwe, P. C. (2000). Improvement of the traditional methods of ogiri production and identification of the microorganism associated with the fermentation process. Journal of Applied Microbiology. 94 (3): 381 - 391.

Odunfa, S.A. and Oyeyiola, G.F. (1985). Microbiological study of the fermentation of 'Ugba' - a Nigerian indigenous fermented food flavor. Journal of Plant Foods. 6: 155-163.

Ofuya, C. O. and Nnajiofor, C. (1989). Development and evaluation of a starter culture for the industrial production of gari. Journal of Applied Bacteriology. 66: $37-42$.

Ogueke, C. C. and Nwagwu, A. (2007). Comparative study of melon seeds (Citrullus vulgaris) fermented with mixed cultures and pure cultures of bacteria isolates from Ogiri Egusi. Life Science Journal. 4 (4): 41 - 46.

Ogunsua, A. O. (2000). Biochemist's adventure into the processing and preservation of foods. Nigerian Universities Inaugural Lectures Series. National Universities Comission, Abuja, Nigeria. pp. 276 280.

Ogunsanwo, B. M., Fabya, O. O., Idowu, O. R., Ikotun, T. and Akano, D. A. (1989). The fate of aflatoxins during the production of ogiri, a West African fermented melon seed condiment from artificially contaminated seeds. Nahrung. 33 (10): 983 - 988.

Ouoba, L.I.I., Parkouda, C., Diawara, B., Scotti, C. and Varnam, A.H. (2008). Identification of Bacillus spp from Bikalga, fermented seeds of Hibiscus sabdariffa: phenotypic and genotypic characterization. Journal of Applied Microbiology. 104: 122-131. 
Pham, C. B. and Del-Rosario, R.R. (1983). The preparation of protein hydrolysate from deffated coconut and soya-bean meals. Effect of process variable on the amino-nitrogen released and flavour development. Journal of Food Technology. 18: 21.

Sanni, A. I., Ayenor, G. S., Sakyi-Dawson, E. and SefaDedeh, S. (2000). Aerobic spore forming bacteria and chemical composition of some Nigerian fermented soup condiments. Plant Foods for Human Nutrition. 55 (2): 111 - 118.

Steinkraus, K. H. (1995). Handbook of indigenous fermented foods. Cornell University, New York. pp. 349 - 356. 